\title{
SPRAWOZDANIE Z KONFERENCJI KOŚCIÓL, KULTURA, POLITYKA W PAŃSTWIE PIERWSZYCH PIASTÓW, (INSTYTUT NAUK HISTORYCZNYCH UKSW, WARSZAWA I PAŃSTWOWA WYŻSZA SZKOLA ZAWODOWA W CIECHANOWIE 22-23 PAŹDZIERNIKA 2015 R.)
}

Ogólnopolska konferencja naukowa pod tytułem „Kościół, kultura, polityka w Państwie pierwszych Piastów" odbyła się w dniach 22 - 23 października 2015 roku. Obrady odbywały się na Uniwersytecie Kardynała Stefana Wyszyńskiego w Warszawie oraz w Państwowej Wyższej Szkole Zawodowej w Ciechanowie. Asumptem do tego przedsięwzięcia stała się zbliżająca 1050. rocznica Chrztu Polski. Konferencja odbyła się pod honorowym patronatem Prymasa Polski Jego Ekscelencji Arcybiskupa Wojciecha Polaka oraz Arcybiskupa Warszawskiego Jego Ekscelencji Kardynała Kazimierza Nycza. Tygodnik wSieci Historii, TVP Historia oraz Katolickie Radio Diecezji Płockiej objęło nad konferencją patronat medialny.

Konferencję otworzył ks. prof. dr hab. Waldemar Graczyk, witając wszystkich przybyłych gości oraz prelegentów. Następnie głos zabrał ks. prof. dr hab. Stanisław Dziekoński - Rektor Uniwersytetu Kardynała Stefana Wyszyńskiego w Warszawie. Następnie głos zabrał doc. dr Leszek Zygner - Rektor Wyższej Szkoły Zawodowej w Ciechanowie. Jako ostatni wypowiadał się ks. dr hab. prof. UKSW Janusz Węgrzecki. Konferencja zebrała największych specjalistów z zakresu historii średniowiecza i innych nauk z wielu ośrodków naukowych. $\mathrm{Na}$ podkreślenie zasługuje również fakt żywego zainteresowania tematem przewodnim konferencji wśród licznie przybyłych słuchaczy.

Pierwsza część obrad poświęcona była Kościołowi w państwie pierwszych Piastów, a jej poprowadzenia podjął się biskup gliwicki prof. dr hab. Jan Kopiec. Pierwszy referat pt. „Chrzest Polski - zmiana cywilizacyjna i polityczna” wygłosił prof. dr hab. Jerzy Strzelczyk. W swojej wypowiedzi profesor podkreślił, że rok 966 to pewien symbol, a samo przyjęcie Chrztu to długi proces. Kolejnym referentem był prof. dr hab. Wojciech Fałkowski, który pochylił się nad zagadnieniem „Misji chrześcijańskiego władcy”. Analiza tematu wykazała, iż władca był wspomożycielem i opiekunem pod względem państwowym, ochronnym oraz religijnym.

Po przerwie głos zabrała prof. dr hab. Beata Wojciechowska, która przedstawiła temat „Organizacja kościelna w Polsce pierwszych Piastów - ujęcia polskiej historiografii”. Profesor Wojciechowska przeanalizowała stan badań nad szeroko pojętą organizacją kościelną w początkach Polski. Kolejnym referentem był dr Waldemar Könighaus, który przedstawił 
swój pogląd na temat „Papiestwa i pierwszych Piastów. Wzajemne stosunki u zarania państwowości Polski”. Prelegent zwrócił swoją uwagę przede wszystkim na problem pojedynczych, bardzo słabych kontaktów między państwem polskim a Stolicą Apostolską. Ostatnim referentem w tej sesji był prof. dr hab. Tomasz Jasiński. Wykład traktował o „Początkach rocznikarstwa Polskiego" i zwracał uwagę na to, że zapiski kronikarskie, które dotarły do Krakowa, zaczerpnęliśmy z Czech, jednakże nie można dokładnie stwierdzić, kiedy to nastąpiło.

Po przerwie nastąpiło rozpoczęcie drugiego panelu, który poświęcony był polityce. Tę sekcję prowadził prof. dr hab. Marek D. Kowalski. Jako pierwszy zaprezentował swój referat prof. dr hab. Antoni Barciak, który zajął się problemem „Kryzysu lat 30-tych XI wieku”. Profesor omawiał szeroko pojęte czynniki kryzysu, czyli walkę o władzę, wewnętrzne rozbicie państwa i uznanie zwierzchnictwa cesarza nad Polską. Prelegent zwrócił uwagę na to, iż był to pierwszy w dziejach naszego państwa poświadczony bunt społeczny, który nie był (wbrew powszechnej opinii) od początku buntem religijnym. Kolejnym problemem poruszonym na konferencji był konflikt między „Biskupem Stanisławem a Bolesławem Szczodrym". Wykład na ten temat wygłosił prof. dr hab. Krzysztof Skwierczyński, który podjął kwestię bezpośrednich przyczyn wygnania króla Bolesława z Polski. Ostatnim referentem w tej części był prof. dr hab. Stanisław Rosik, który wygłosił referat pt. „Zbigniew i Bolesław Krzywousty, czyli „dwa kocury w jednym worku schwytane”. Anatomia konfliktu w świetle opinii współczesnych". Profesor Rosik przedstawił konflikt pomiędzy braćmi, opierając się na pierwszej Kronice Polskiej Anonima zw. Gallem.

Swoimi badaniami podzielił się również prof. dr hab. Przemysław Wiszewski pochylając się nad tematem „Honor, konflikt i... wartości. Władza Piastów po śmierci Bolesława Krzywoustego". Referent przedstawił wydarzenia tuż po śmierci króla i początek procesu rozbicia dzielnicowego Polski do czasu wygnania królewicza Władysława z Polski w świetle trzech kronik: Anonima zw. Gallem, Mistrza Wincentego i Wielkopolskiej. Ostatnim mówcą był prof. dr hab. Andrzej M. Wyrwa, przedstawiając swoje badania na temat „Architektury murowanej na ziemiach polskich do XII - XIII w. Stan i perspektywy badań. Szkic do problemu". Autor zwrócił uwagę, że o początkach architektury murowanej można mówić już od II poł XI w. Swoje wnioski profesor przedstawił na licznych wykresach.

Drugi dzień konferencji odbywał się w Państwowej Wyższej Szkole Zawodowej w Ciechanowie. Przywitanie gości oraz rozpoczęcie obrad zostało zainicjowane przez doc. dr Leszka Zygnera - Rektora PWSZ w Ciechanowie oraz przez Pierwszego Zastępcę Prezydenta miasta Ciechanowa Panią Joannę Potocką - Rak. Zwróciła ona uwagę na planowane badania archeologiczne, które mają odbywać się na ciechanowskim wzgórzu zamkowym. Następnie doc. dr Zygner przedstawił porządek sekcji tematycznych. Pierwsza sekcja dotycząca Kościoła była prowadzona przez prof. dr hab. Wojciecha Mrozowicza.

Pierwszą prelegentką była prof. dr hab. Jolanta M. Marszalska, która zaprezentowała temat „Książka rękopiśmienna w państwie pierwszych Piastów do połowy XII wieku”. Profesor omówiła tematykę rodzaju ksiąg występujących w środowisku płockim, znaczenie bp. płockiego Aleksandra z Malonne oraz kręgu kultury mozańskiej. Kolejny referat pt. „Szkolnictwo katedralne wraz z kanonem nauczania w Polsce do końca XII w.” przedstawił prof. dr hab. Andrzej Radzymiński. Profesor odniósł się do zagadnienia ksiąg, które zostało poruszone przez prof. Marszalską. Omówił również strukturę polskiego szkolnictwa kościelnego. Ostatnim prelegentem tej części był prof. dr hab. Przemysław Urbańczyk. 
Zaprezentował on referat pt. „Najstarsze materialne świadectwa chrystianizacji ziem polskich”, przedstawiając tezę o wcześniejszym funkcjonowaniu chrześcijaństwa na ziemiach polskich niż w 966 roku.

Tematem przewodnim kolejnego panelu było Mazowsze. Panel prowadzony był przez prof. dr hab. Marian Dygo. Pierwszą osobą w tej sekcji, która prezentowała referat pt. „Mazowsze w państwie Piastów do końca XII w.” był prof. dr hab. Jan Tyszkiewicz. Zaprezentował on skondensowaną historię przynależności państwowej oraz wyznaniowej ziem mazowieckich w początkach średniowiecza. Następnym prelegentem był dr Kazimierz Pacuski, który przedstawił swoje badania na temat „Grodów i kościołów grodowych Mazowsza Północnego w XI i XII wieku”. Wykazał on istotność tzw. falsyfikatu mogileńskiego, który wylicza pierwsze miejscowości powstałe na Mazowszu do wieku XI, a także sieć innych grodów mazowieckich. Kolejną osobą prezentującą temat „Organizacja kościelna na Mazowszu do połowy XII w.” był ks. prof. dr hab. Waldemar Graczyk. Zaprezentowana została problematyka podziału kościelnego ziem mazowieckich we wczesnym średniowieczu.

Następną osobą wygłaszającą referat po przerwie był doc. dr Leszek Zygner, prezentujący temat „Pierwsi biskupi płoccy i duchowieństwo kapitulne”. Prelegent zaprezentował kilka wątpliwości i problemów badawczych dotyczących pierwszych biskupów płockich oraz roli Władysława Hermana, Zbigniewa i Bolesława Krzywoustego, które w jego opinii należy rozwiązać. Jako ostatni wystąpił dr Krzysztof Wiśniewski, prezentujący referat pt. „Zakony na Mazowszu do połowy XII wieku". Zaprezentował on przede wszystkim problematykę związaną z opactwem benedyktynów płockich. Po wygłoszeniu wszystkich referatów nastąpił czas na dyskusję, która podobnie jak poprzedniego dnia, była równie ożywiona. Po jej zakończeniu organizatorzy zamknęli obrady konferencyjne. 